\title{
Naturopathy Education, Social Cognitive Theory, Precede- Proceed Model, and Lesson Plan
}

Lisa Marie Portugal*

USA

*Corresponding author: Lisa Marie Portugal, USA, E-mail: lisamarieportugal@msn.com

\section{Short Communication}

Volume 2 Issue 1

Received Date: January 11, 2018

Published Date: February 03, 2018

\section{Abstract}

Social Cognitive Theory can address appropriate health and wellness change initiatives via the education of groups. Individualized and group action plans can be created and developed to address the overall health and wellness needs of families. This model and theory can assist in the education of preventing disease through health promotion and education and from a naturopathy perspective. In addition, this model can assist in the development of health educational programs to understand and explain health behaviors and choices families make. The model can guide useful strategies and educational tools with in-person or online instructional modules.

Keywords: Social Cognitive Theory; Behavioral Change Models; Health Belief Model; Health Education; Self-Regulatory Capability

Abbreviations: CBT: Cognitive Behavioral Theory; SCT: Social Cognitive Theory.

\section{Problem Statement}

Poor health, poor diet, disease, and many health challenges plague Western nation populations. This paper outlines how: (1) Behavioral Change Models, (2) The Health Belief Model, and (3) Social Cognitive Theory can be used to help individuals learn about toxic food choices, poor diet, and the cause of disease. A fully developed lesson plan is included with accompanying interactive learning resources to instruct adolescents and adults about how a fast food diet directly relates to disease and poor health. Health educators can use the information, lesson plan, and learning materials to educate adolescents, adults, seniors, families, and classroom students individually or in groups. Furthermore, the lesson plan can be used in a face-to-face learning environment or in synchronous and/or asynchronous online learning platforms.

\section{Introduction}

The basic assumptions/principles of The Health Belief model can be relevant when working with diverse adults or youth while incorporating strategies, techniques, and methods rooted in specific learning theories and behavior modification concepts. Health educators can apply proven best practices used in the classroom to educate individuals about health, wellness, disease, and selfdirected action that can improve lives. Moreover, with the use of technology integration, online instructional 


\section{Journal of Natural \& Ayurvedic Medicine}

modules, and social media, a global audience can be reached and informed as well [1-3].

Behavioral Change Models, The Health Belief Model, and Social Cognitive Theory can help health educators inform and educate individuals how to be more proactive in their own lives. This can be achieved by addressing the myths and misinformation individuals may believe about themselves and about health topics and/or remedies available. A fully developed lesson plan for adolescents and adults has been included to help raise awareness of toxic food, poor health, and disease challenges caused by a Western diet. The following concepts are graphed in order below: (1) Behavioral Change Models, (2) The Health Belief Model, and (3) Social Cognitive Theory.

\section{- Transtheoretical Model}

- Stages of Change

\begin{tabular}{|c|c|}
\hline $\begin{array}{c}\text { Pre- } \\
\text { contemplation }\end{array}$ & $\begin{array}{c}\text { No intention to take action within the } \\
\text { next } 6 \text { months }\end{array}$ \\
\hline Contemplation & $\begin{array}{c}\text { Intends to take action within the next } \\
6 \text { months }\end{array}$ \\
\hline Preparation & $\begin{array}{c}\text { Intends to take action in the next 30 } \\
\text { day; has taken some steps }\end{array}$ \\
\hline Action & $\begin{array}{c}\text { Changed overt behavior for less than } \\
6 \text { months }\end{array}$ \\
\hline Maintenance & $\begin{array}{c}\text { Changed overt behavior for more } \\
\text { than } 6 \text { months }\end{array}$ \\
\hline Termination & $\begin{array}{c}\text { No temptation to relapse and } 100 \% \\
\text { confidence }\end{array}$ \\
\hline
\end{tabular}

Table 1: Behavioral Change Models can include the following.

Adapted from Portugal LM. How to use theory in health education to change lives: Interventions \& strategies. [4]

\begin{tabular}{|c|c|}
\hline Consciousness Raising & Finding and learning new facts, ideas, and tips to support the healthy behavior change \\
\hline Dramatic Relief & Experiencing negative emotions of unhealthy behavior \\
\hline Self-reevaluation & Realizing that behavior change is an important part of one's identity as a person \\
\hline Environmental Reevaluation & $\begin{array}{l}\text { Realizing the negative impact of unhealthy behavior or the positive impact of healthy } \\
\text { behavior on one's proximal social and/or physical environment }\end{array}$ \\
\hline Self-liberation & Making a firm commitment to change \\
\hline Helping Relationships & Seeking and using social support for the healthy behavior change \\
\hline Counterconditioning & Substitution of healthier alternative behaviors and cognitions for the unhealthy behavior \\
\hline Reinforcement Management & $\begin{array}{c}\text { Increasing the rewards for the positive behavior change and decreasing the rewards } \\
\text { of the unhealthy behavior }\end{array}$ \\
\hline Stimulus Control & $\begin{array}{c}\text { Removing reminders or cues to engage in the unhealthy behavior and adding cues or } \\
\text { reminder to engage in the healthy behavior }\end{array}$ \\
\hline Social Liberation & $\begin{array}{l}\text { Realizing that the social norms are changing in the direction of supporting the healthy } \\
\text { behavior change }\end{array}$ \\
\hline
\end{tabular}

Table 2: Processes of Change.

Adapted from Portugal LM. How to use theory in health education to change lives: Interventions \& strategies [4].

\begin{tabular}{|c|c|}
\hline Pros & Benefits of changing \\
\hline Cons & Costs of changing \\
\hline
\end{tabular}

Table 3: Decisional Balance.

Adapted from Portugal LM. How to use theory in health education to change lives: Interventions \& strategies [4]

\begin{tabular}{|c|c|}
\hline Confidence & $\begin{array}{c}\text { Confidence that one can engage in the } \\
\text { healthy behavior across different } \\
\text { challenging situations }\end{array}$ \\
\hline Temptation & $\begin{array}{c}\text { Temptation to engage in the unhealthy } \\
\text { behavior across different challenging } \\
\text { situations }\end{array}$ \\
\hline
\end{tabular}

Table 4: Self-Efficacy.
Adapted from Portugal LM. How to use theory in health education to change lives: Interventions \& strategies [4].

\begin{tabular}{|c|c|}
\hline Construct & Definition \\
\hline $\begin{array}{c}\text { Attitude toward } \\
\text { a behavior }\end{array}$ & $\begin{array}{c}\text { Value placed on a behavior that can } \\
\text { be either positive or negative }\end{array}$ \\
\hline Subjective norms & $\begin{array}{c}\text { Beliefs about what others think we } \\
\text { should do and the degree we are } \\
\text { motivated by what others think }\end{array}$ \\
\hline Perceived control & $\begin{array}{c}\text { Belief that a behavior is within one's } \\
\text { control, noting that perception of a } \\
\text { behavior performance } \\
\text { (hard or simple) will affect intention }\end{array}$ \\
\hline
\end{tabular}

Table 5: Theory of Reasoned Action and Theory of Planned Behavior. 


\section{Journal of Natural \& Ayurvedic Medicine}

Adapted from Portugal LM. How to use theory in health

education to change lives: Interventions \& strategies [4].

\begin{tabular}{|c|c|}
\hline Construct & Definition \\
\hline Attitude toward a behavior & Value placed on a behavior that can be either positive or negative \\
\hline Experiential attitude & Emotional response to the idea of performing a behavior \\
\hline Instrumental attitude & Cognitive response to beliefs about the outcomes \\
\hline Subjective norms & $\begin{array}{c}\begin{array}{c}\text { Beliefs about what others think we should do and the degree we are motivated by what } \\
\text { others think }\end{array} \\
\text {. }\end{array}$ \\
\hline Injunc & What others think an individual should do \\
\hline Descriptive norm & What others in an individual's social networks would do \\
\hline Personal Agency & $\begin{array}{c}\begin{array}{c}\text { Bringing an individual's influence to bear on his/her own functioning and environmental } \\
\text { events }\end{array} \\
\text { ( }\end{array}$ \\
\hline Perceived control & $\begin{array}{c}\text { An individual's perceived amount of control over behavioral performance based on } \\
\text { environmental factors }\end{array}$ \\
\hline Self-efficacy & An individual's confidence in performing a behavior in the context of barriers \\
\hline
\end{tabular}

Table 6: Integrated Behavior Model.

Adapted from Portugal LM. How to use theory in health education to change lives: Interventions \& strategies [4].

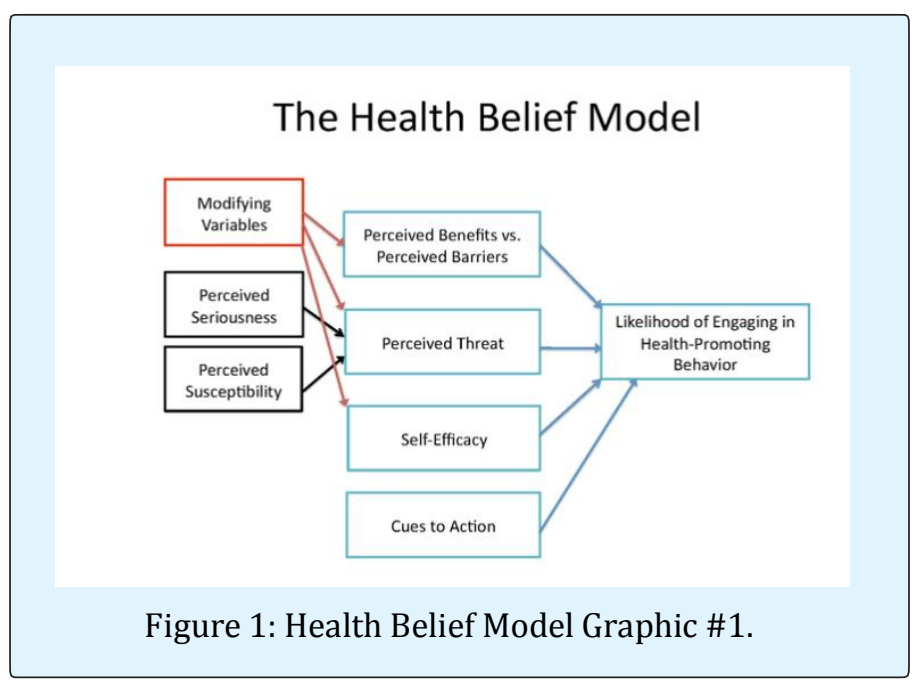

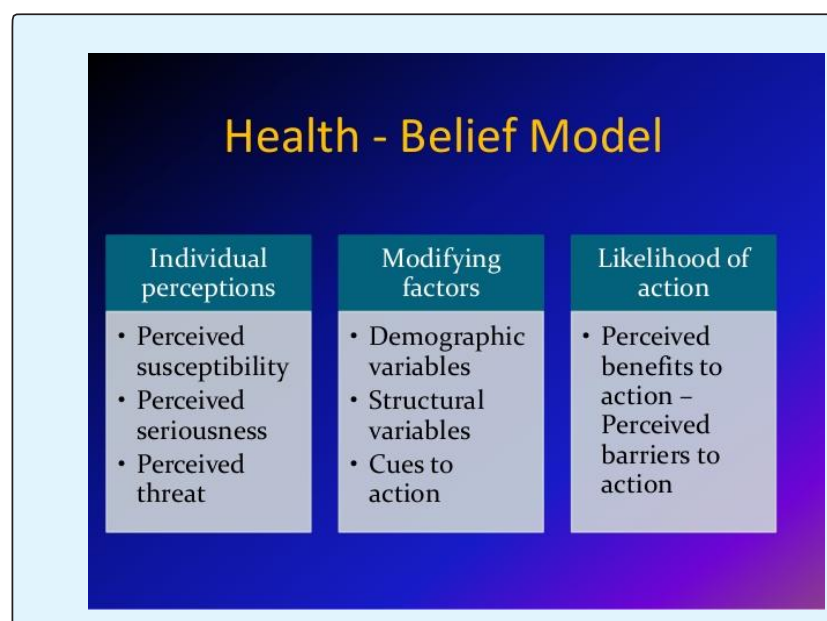

Figure 2: Health Belief Model Graphic \#2.

Adapted from Smith HEALTHY LIVING - Health belief models [5].

\begin{tabular}{|c|c|c|c|}
\hline Concept & Definition & $\begin{array}{l}\text { Individual's } \\
\text { Perceptions }\end{array}$ & $\begin{array}{l}\text { Health Educator's } \\
\text { Next Action }\end{array}$ \\
\hline Perceived Susceptibility & $\begin{array}{l}\text { The chance an individual beliefs they have of getting a } \\
\text { specific health condition. }\end{array}$ & & \\
\hline Perceived Severity & $\begin{array}{l}\text { How severely the individual believes a certain health } \\
\text { condition will affect their life. }\end{array}$ & & \\
\hline Perceived Benefits & $\begin{array}{l}\text { The benefits individuals believe there are in taking action } \\
\text { to address the health condition. }\end{array}$ & & \\
\hline Perceived Barriers & $\begin{array}{c}\text { The road blocks or threats individuals anticipate in try to } \\
\text { address the health condition. }\end{array}$ & & \\
\hline Cue to Action & $\begin{array}{l}\text { External or internal factors that stimulate individuals to } \\
\qquad \text { act. }\end{array}$ & & \\
\hline Self-Efficacy & $\begin{array}{l}\text { The level of confidence individuals have in their ability to } \\
\text { act. }\end{array}$ & & \\
\hline
\end{tabular}

Table 7: Health Belief Model Mapping Template. 


\section{Journal of Natural \& Ayurvedic Medicine}

Adapted from Portugal LM How to use theory in health education to change lives: Interventions \& strategies [4].

\section{Interpersonal Theory - Social Cognitive Theory}

There are three variables that interrelate in Social Cognitive Theory. Those variables can cause learning to happen and include (1) the individual's personal experiences, (2) behavioral determinants, and (3) environmental factors. Positive learning can be the affect along with changed negative patterns and a new way of thinking and behaving can develop.

The basic concepts of Social Cognitive Theory include: (1) observational learning, (2) self-regulatory capability, (3) reproduction, (4) self-efficacy, and (5) emotional coping. The concept of emotional coping explains how better coping mechanisms can be cultivated to address stressful environments and negative behaviors. Fostering and developing this skill can lead to compelling and powerful learning in youth and adults. Self-efficacy is the process and ability of improving on newly learned information, knowledge, and practiced behaviors.

Cognitive Learning Theory has two specific branches called Social Cognitive Theory (SCT) and Cognitive Behavioral Theory (CBT) [6]. Social Cognitive Theory basic concepts include emotional coping, self-efficacy, self-regulatory capability, reproduction, and observational learning. Emotional coping is the notion that good coping mechanisms can be developed to address negative behaviors and stressful environments [6]. Developing and fostering this skill can lead to powerful and compelling learning in youth and adults. The process of self-efficacy is the ability to improve upon newly learned knowledge, information, and behavior with practice.

Self-regulatory capability is the ability to control one's behavior in challenging, difficult, stressful environments. Reproduction is a process educators can use to place individuals in a safe, learning environment where materials and information can be viewed, heard, touched, experienced, and processed to help retain knowledge, learned behaviors, and practice changes. Observational learning is the notion that individuals learn by observing as a means of attaining knowledge, information, and changing behavior. Based on the Social Cognitive Theory suggestions for influencing behavioral change would be to educate families, parents, and youth about the toxic poisons in fast foods, snacks, brand products, and prepackaged, boxed foods from the grocery store.

\section{According to Portugal (2017)}

Social Cognitive Theory has three variables that interrelate with each other which can then cause learning to happen [4]. The individual's personal experiences can come together with behavioral determinants and environmental factors to create positive learning, change negative patters, and develop new ways of thinking and behaving. (p. 282)

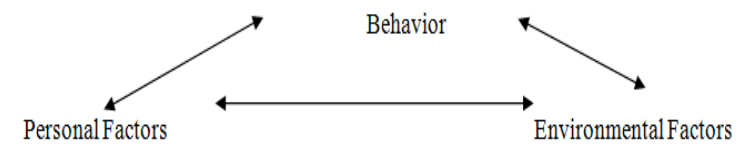

Figure 3: Social Cognitive Theory of Personality. (Cognitive, affective, \& biological events) (p. 282)

Some of the ways one can educate others is by creating health and wellness interactive, intuitive lesson plans, writing peer-reviewed articles, writing health books, developing a database of resources, sharing educational resources and instructional tools on websites, creating educational technology tools, and delivering real facts, real news, and real science to others. Below is an example of how I use an instructional technology avatar that I created about the toxic, poisoned food at McDonald's.

\section{Ten horrifying ingredients that prove McDonald's is not fit for consumption http://www.voki.com/presenter/playPresentation.php?i $\mathrm{d}=\mathrm{cef} 37 \mathrm{~d} 99 \mathrm{da6}$ eac37866c2e15c46c39cf}

\section{Applying Social Cognitive Theory}

Social Cognitive Theory constructs can be applied to health behaviors by addressing health needs of families and parents in any group and in any region or country. The instructional tools can be created in any language once the basics of the curriculum have been written. The program can be taught in person via workshops, in clinics, or can be accessed online globally. The curriculum can be taught individually or in groups as well. Individualized learning styles, culture, and environment on the target population can be addressed using adult learning theories, scaffolding instructional techniques, differentiated instructional strategies, and technology integration to meet the needs of parents and families where they are at cognitively. These methods can assist in raising parent's and family's awareness in an interactive, intuitive manner regarding health and wellness education [4,7-10]. 


\section{Journal of Natural \& Ayurvedic Medicine}

A holistic, qualitative approach can be used to address specific needs, ailments, health challenges, cultural background, and ability levels of groups and families. In addition, cognitive dissonance theory must be taken into account when developing this type of health and wellness program to address misinformation the public has been indoctrinated with over many years. The key is to address families and parents with a holistic, individualized, naturopathy perspective over a Big Pharma, prescriptiondriven, one-size-fits-all system emblematic of allopathic practitioners [8-10]. The goal is to self-empower, educate, change negative habits, and assist in the development of lifelong healthy habits [4]. Furthermore, the plan can address the value of whole body healing from a naturopathy medicinal perspective [2]. A compare and contrast of allopathic versus naturopathic practices can be examined and built into the curriculum.

\section{Social Cognitive Theory Mapping Template}

This example involves a group of parents. The parents have children of all ages and they tend to take family members to allopathic doctors mainly when someone is sick for vaccines, pharmaceutical drugs, antibiotics, and surgery. The goal is to educate parents and family members about (1) preventative healthcare / self-care in the home, (2) natural remedies found in nature, (3) natural nonGMO, Paleolithic diet or Paleo diet, and (4) using naturopathy doctors, providers, and services rather than allopathic and pharmaceutical services for healthcare needs [2].

\begin{tabular}{|c|c|c|c|}
\hline Construct & Definition & \multirow[b]{3}{*}{$\begin{array}{l}\text { Scenario } \\
\text { Parent's surroundings are dominated by } \\
\text { a busy schedule not allowing them time } \\
\text { to do research on allopathic versus } \\
\text { naturopathic medicine, natural } \\
\text { healthcare remedies versus } \\
\text { pharmaceutical drugs, vaccines, surgery } \\
\text { and the damaging affects of allopathic } \\
\text { treatments. (Environment influencing } \\
\text { the parent's health behaviors) The } \\
\text { parents can have the desire and ability } \\
\text { to change their environment to increase } \\
\text { their knowledge and awareness in these } \\
\text { areas. (People influencing the } \\
\text { environment for a change in health } \\
\text { behavior). }\end{array}$} & Health Educator's Next Action \\
\hline & $\begin{array}{l}\text { People Influence } \\
\leftarrow \rightarrow\end{array}$ & & \multirow[b]{2}{*}{$\begin{array}{l}\text { Present to parents how they can } \\
\text { change their environment to allow } \\
\text { participation in healthcare } \\
\text { education, awareness, and } \\
\text { trustworthy news. }\end{array}$} \\
\hline $\begin{array}{l}\text { Reciprocal } \\
\text { Determinism }\end{array}$ & $\begin{array}{l}\text { Environment } \\
\text { Influence }\end{array}$ & & \\
\hline $\begin{array}{l}\text { Outcome } \\
\text { Expectancy }\end{array}$ & $\begin{array}{l}\text { Beliefs about the } \\
\text { likelihood and } \\
\text { value of the } \\
\text { consequences of } \\
\text { behavioral choices }\end{array}$ & $\begin{array}{l}\text { Address parent's belief in their desire } \\
\text { and ability to make changes to } \\
\text { environment to enhance healthcare } \\
\text { education, raising awareness, and } \\
\text { trustworthy news. }\end{array}$ & $\begin{array}{l}\text { Examine if the parents believe it } \\
\text { might be possible to make changes } \\
\text { in their environment to educate } \\
\text { themselves about healthcare best } \\
\text { practices and trustworthy news. } \\
\text { Assess whether parents might value } \\
\text { health consequences associated } \\
\text { with making behavioral changes. }\end{array}$ \\
\hline Self-Efficacy & $\begin{array}{l}\text { Beliefs about the } \\
\text { ability to perform } \\
\text { behaviors that } \\
\text { bring desired } \\
\text { outcomes }\end{array}$ & $\begin{array}{c}\text { Parents perceive they can make change } \\
\text { happen. }\end{array}$ & $\begin{array}{l}\text { Examine whether parents are } \\
\text { assertive about making changes in } \\
\text { schedules to engage in healthcare } \\
\text { education, raising their awareness, } \\
\text { and learning where to find } \\
\text { trustworthy news. }\end{array}$ \\
\hline $\begin{array}{l}\text { Collective } \\
\text { Efficacy }\end{array}$ & $\begin{array}{l}\text { Beliefs about the } \\
\text { ability of a group } \\
\text { to perform } \\
\text { concerted actions } \\
\text { that bring desired } \\
\text { outcomes }\end{array}$ & $\begin{array}{l}\text { Parents in the group, neighborhoods, } \\
\text { area, schools, churches, communities, } \\
\text { etc. can form the social network. In } \\
\text { addition, social networks can also be } \\
\text { formed via the Internet, social media } \\
\text { sites, and websites to connect globally } \\
\text { as well. }\end{array}$ & $\begin{array}{l}\text { Investigate parent's social network } \\
\text { and determine who might be } \\
\text { supportive of new behavioral } \\
\text { changes. Buddy systems can be } \\
\text { beneficial to assist in holding groups } \\
\text { of parents and families accountable } \\
\text { to each other. In addition, new }\end{array}$ \\
\hline
\end{tabular}




\section{Journal of Natural \& Ayurvedic Medicine}

\begin{tabular}{|c|c|c|c|}
\hline & & & $\begin{array}{l}\text { learning and sharing can assist in } \\
\text { behavioral changes as well. }\end{array}$ \\
\hline $\begin{array}{l}\text { Observational } \\
\text { Learning }\end{array}$ & $\begin{array}{l}\text { Learning to } \\
\text { perform new } \\
\text { behaviors by } \\
\text { exposure to } \\
\text { interpersonal, or } \\
\text { media displays of } \\
\text { them, particularly } \\
\text { through peer } \\
\text { modeling } \\
\end{array}$ & $\begin{array}{l}\text { Parents can learn how to make } \\
\text { achievable targets, establish sensible } \\
\text { outcomes, and promote techniques to } \\
\text { defeat a lack of healthcare education, } \\
\text { awareness, and barriers in accessing } \\
\text { trustworthy news. }\end{array}$ & $\begin{array}{l}\text { Design in-person and online } \\
\text { workshops, instructional modules to } \\
\text { assist parents in the development of } \\
\text { realistic goals, decide on achievable } \\
\text { outcomes, and tailor techniques to } \\
\text { overcome lack of healthcare } \\
\text { education, awareness, and barriers } \\
\text { in accessing trustworthy news. }\end{array}$ \\
\hline $\begin{array}{l}\text { Incentive } \\
\text { Motivation }\end{array}$ & $\begin{array}{l}\text { The use and } \\
\text { misuse of rewards } \\
\text { and punishments } \\
\text { to modify } \\
\text { behavior }\end{array}$ & $\begin{array}{c}\text { Assess how to motivate parents to } \\
\text { engage with self-educational activities. } \\
\text { Assess what might be barriers to } \\
\text { motivation, engagement, and } \\
\text { participation in self-educational } \\
\text { activities. }\end{array}$ & $\begin{array}{l}\text { Distinguish motivating and de- } \\
\text { motivating elements }\end{array}$ \\
\hline Facilitation & $\begin{array}{l}\text { Providing tools, } \\
\text { resources, or } \\
\text { environmental } \\
\text { changes that make } \\
\text { new behaviors } \\
\text { easier to perform }\end{array}$ & $\begin{array}{l}\text { Some brief examples might include: } \\
\text { journaling, scheduling, calendar to plan } \\
\text { week to engage in self-education } \\
\text { activities. Promote examples of peer, } \\
\text { group, parent, and family successes. }\end{array}$ & $\begin{array}{l}\text { Provide the parents with tools and } \\
\text { resources to better equip } \\
\text { themselves for participation in } \\
\text { healthcare education, awareness, } \\
\text { and trustworthy news. }\end{array}$ \\
\hline Self-Regulation & $\begin{array}{l}\text { Controlling } \\
\text { oneself through } \\
\text { self-monitoring, } \\
\text { goal-setting, } \\
\text { feedback, self- } \\
\text { reward, self- } \\
\text { instruction, and } \\
\text { enlistment of } \\
\text { social support } \\
\end{array}$ & $\begin{array}{l}\text { Parents will self-monitor own time to } \\
\text { schedule self-educational activities. } \\
\text { Parents can set own time management } \\
\text { for self-educational activities, self- } \\
\text { monitor, and meet achievable goals. In } \\
\text { addition, instructional modules can } \\
\text { build-in time management tools, } \\
\text { monitors, and assessment systems. }\end{array}$ & $\begin{array}{l}\text { Explain how mechanisms built into } \\
\text { the program might assist parents in } \\
\text { achieving self-awareness and self- } \\
\text { education. Instructional modules } \\
\text { can be created that are intuitive, } \\
\text { easy-to-use, track performance, } \\
\text { track participation, track additional } \\
\text { educational needs. }\end{array}$ \\
\hline $\begin{array}{c}\text { Moral } \\
\text { Disengagement }\end{array}$ & $\begin{array}{l}\text { Ways of thinking } \\
\text { about harmful } \\
\text { behaviors and the } \\
\text { people who are } \\
\text { harmed that make } \\
\text { infliction of } \\
\text { suffering } \\
\text { acceptable }\end{array}$ & $\begin{array}{l}\text { By non-engagement in self-educational } \\
\text { activities, unhealthy life choices and } \\
\text { misinformation from the wrong sources } \\
\text { can have damaging effects on the family. } \\
\text { Misinformation about healthcare is } \\
\text { damaging and harmful to the family and } \\
\text { also encourages same negative } \\
\text { behaviors and choices made by children. } \\
\text { The inability to self-educate can, in turn, } \\
\text { be harmful to the children. }\end{array}$ & $\begin{array}{l}\text { Assess what can assist in limiting } \\
\text { harm of being unknowledgeable, } \\
\text { uniformed, and uneducated. } \\
\text { Promote healthcare education, } \\
\text { awareness and trustworthy news } \\
\text { for the whole family. Explain } \\
\text { methods parents can use to educate } \\
\text { others in their sphere of influence as } \\
\text { well. }\end{array}$ \\
\hline
\end{tabular}

Table 8: Naturopathy Healthcare Social Cognitive Theory Mapping.

Adapted from Portugal LM. How to use theory in health education to change lives: Interventions \& strategies [4].

This plan addresses the existing health behaviors to help parents and families make a behavioral change by (1) educating them with appropriate tools according to their needs, (2) informing them with current news (3) supporting them with multiple resources, services, providers, and alternatives, (5) providing support group access, and 4) providing follow-up, check-in or touch-base services, and on-going educational tools [4]. This Social Cognitive Theory Mapping template is merely the vision or mapping out of overall goals and objectives. The specifics and details are created in a health and wellness educational plan and change initiative. Within a health and wellness educational plan, theories, principals, goals, objectives, strategies, techniques, instructional modules, workshops, services, providers, and program development tools are explained in further detail and depth. 


\section{Journal of Natural \& Ayurvedic Medicine}

\section{PRECEDE-PROCEED Model \\ Implementation}

PRECEDE-PROCEED Implementation Model is applied in the example Social Cognitive Theory Mapping involving a group of parents [1]. The example is provided for parents with children of all ages who tend to take family members to allopathic doctors most often for vaccines, pharmaceutical drugs, antibiotics, and surgery. The goal of this PRECEDE-PROCEED model is to educate and inform parents and family members about (1) preventative healthcare / self-care in the home, (2) natural remedies found in nature, (3) natural nonGMO, Paleolithic diet or Paleo diet, and (4) using naturopathy doctors, providers, and services rather than allopathic and corporate pharmaceutical services for healthcare needs [2].

\section{PRECEDE has four phases}

\section{Phase 1}

The program's desired result is to educate parents and families about naturopathy doctors, services, providers, and healing remedies versus allopathic and Big Pharma services. The main goals of this PRECEDE-PROCEED Implementation Model are to (1) educate and inform with specific tools, resources, curriculum, and real news / studies, (2) change health behaviors, (3) change how individuals view allopathic versus naturopathy medicine, doctors, services, and providers, (4) offer new healthcare alternatives, choices, services, and resources, and (5) help parents and families spread newly learned knowledge to others within the target population's sphere of influence $[11,12]$. Changed negative behaviors into positive health choices are expected as well as newly gained information about how to be more proactive in healthcare education for the whole family using naturopathy services rather than allopathic, corporate pharmaceuticals.

\section{Phase 2}

The following priorities for the health behavior issue include:

- The environmental and behavioral determinants impeding the actualization of the desired results are fake news, fake studies written by agenda-driven, big money agencies, false indoctrination, media brainwashing on television, magazines, radio, Internet, billboards (basically all media in Western nations), false medical information disseminated to the public via allopathic medical system and pharmaceutical companies

- The conditions that need to be addressed to achieve the desired results include: (1) an openness and wiliness on the part or families and parents to learn new healthcare information, (2) time in busy lifestyles, (3) space such as in-person and/or online assessment, curriculum modules, resources, and (4) access to service providers willing to participate and educate in the change agenda.

- The environmental factors, lifestyles, and/or behaviors that influence the conditions or issues include messaging from all Western culture systems that bombard the target population with incorrect information about healthcare, healthcare choices, and the real cause of illness and disease. In addition, busy lifestyles do not help parents and families understand (or even know the importance of) how to filter out inaccurate information they are bombarded with daily and where to seek accurate healthcare information. Finally, unhealthy behaviors regarding diet and eating habits are reinforced in Western nations and the target population does not have the full awareness about their poor choices.

\section{Phase 3}

- Predisposing circumstances affecting environmental, attitudes, and behavioral factors having influence in Phase 2 include false indoctrination within the culture about healthcare education, healthcare / self-care, and naturopathy medical services versus allopathic, corporate pharmaceutical indoctrination.

- Enabling circumstances affecting environmental, attitudes, and behavioral factors having influence in Phase 2 include easy access to toxic prescription pharmaceutical drugs, toxic over-the-counter drugs, vaccines, surgery, fast food restaurants, and unhealthy pre-made brand grocery store foods rather than choosing natural foods that can take more time to prepare. Other enabling factors include all Western media avenues that bombard families with false information daily.

- Reinforcing circumstances affecting environmental, attitudes, and behavioral factors having influence in Phase 2 include everyone in the target population's lifestyle and sphere of influence are mostly likely indoctrinated with false information as well. All corporate big media avenues and the allopathic, pharmaceutical medical system serve as reinforcing agents disseminating false healthcare information and enabling dependency rather than fostering selfadvocacy, self-efficacy, and the ability to self-educate or self-inform.

\section{Phase 4}

The policy and administrative factors influencing what can be implemented include building a coalition of naturopathy doctors, clinics, services providers, and educators. In addition, building a database of resources, tools, services, and curriculum modules must be provided to the target population. Finally, training needs to be 


\section{Journal of Natural \& Ayurvedic Medicine}

provided to the target population on how to use and access the tools $[11,12]$.

\section{PROCEED has four phases}

\section{Phase 5}

\section{- The Implementation Design}

Social Cognitive Theory constructs will be applied to health behaviors of the target population. The design involves "creating in-person and online workshops and instructional modules to assist parents in the development of realistic goals, decide on achievable outcomes, and tailor techniques to overcome lack of healthcare education, awareness, and barriers in accessing trustworthy news" [4]. The intervention will be conducted by addressing the healthcare needs of parents and families in a comprehensive naturopathy manner with before, during, and after medical and curriculum assessment.

\section{Phase 6}

\section{- The Process Evaluation}

Medical and curriculum assessment will be on-going, tracked, monitored, and reported at the beginning, during, and end of the change initiative. Data will be compiled to address gaps, changes, revisions, alterations, individualized, and personalized needs of the target population. This will be done by on-going surveys, interviews, testing, and tracking of involvement in the curriculum.

\section{Phase 7}

\section{- The Impact Evaluation}

The impact evaluation involves the monitoring and reporting aspects of (1) how well the target population learned the new information, (2) how much time was spent involved in the learning activities, and (3) whether the new information was actually applied in the daily choices, behaviors, and actions taken by the target population. The desired impact of this intervention on the target population will be real and evident behavioral changes in the lives of parents, families, children, and individuals in their sphere of influence by way of improved health, less illness and ability to overcome illness faster, elevated self-efficacy levels, changes made in healthcare advisors and service providers $[11,12]$. The impact evaluative process will include direct observations, surveys, interviews, curriculum assessments, and before, during, and after medical assessments. All of the reporting and monitoring aspects listed can be done in a variety of ways such as in-person, telephone, email, online, and via curriculum module completion (1) testing, and (2) tracking.

\section{Phase 8}

\section{- The Outcome Evaluation}

The outcome evaluative process will be the same as the impact evaluation process which includes direct observations, surveys, interviews, curriculum assessments, and before, during, and after medical assessments. All of the reporting and monitoring aspects listed can be done in a variety of ways such as in-person, telephone, email, online, and via curriculum module completion (1) testing, and (2) tracking. Both quantitative and qualitative measures will be used throughout the program to assess, measure, track, and report findings [13].

\section{Reflection}

The most beneficial aspects of this material includes the ability to learn new ways of thinking, applying theory in one's best practices when educating others about healthcare, and interlinking theory with practical application. Practitioners, health educators, students, researchers, and community members should feel more prepared and confident choosing applicable models of evaluation as they study, practice, and apply various theoretical concepts when incorporated into their own program's evaluation needs and complexity [14]. The materials presented here can help health educators: (1) understand frameworks for building capacity, (2) understand the role of health programs and policies, (3) understand the role of evaluation and assessment, and (4) apply theory-based health practices to any community health education program or agenda [14-16].

The skills and knowledge learned can be applied in both personal and professional life using theory, strategies, and intervention models to educate self, family, friends, neighbors, community, and professional associations. In addition, one can educate others in a professional capacity by understanding positive and negative influencing factors in the lives of others. Theory can be applied in personal, individualized, meaningful ways to capture the attention of others and help raise selfadvocacy and self-efficacy levels for better health conditions and better health choices [17-20].

As a result of the materials presented here, one can feel confident in his or her abilities to effectively teach others how to improve health circumstances in a professional, theory-based manner. The tools presented in this paper can help health educators, practitioners, students, researchers, and community members feel more confident in having the ability to reach individuals and groups where they are at cognitively and work toward 


\section{Journal of Natural \& Ayurvedic Medicine}

raising those abilities to higher levels of thinking, awareness, and proactive self-care / healthcare [21-23]. Important goals to consider are to: (1) learn new ways of thinking, researching, and healing, (2) teach others, and (3) pass the knowledge on within spheres of influence.

\section{Lesson Plan}

\section{Fast Food and Cancer Link}

Fast food and a poor diet cause Cancer, Diabetes, Lupus, and many other diseases. This lesson plan will prove the undisputable links between all disease and a common Western diet [24-26]. Cancer and many diseases are also caused by other factors in the environment such as genetically modified foods (GMO's), flu shots, child and adult vaccines, prescription drugs, and over-the-counter drugs. The categories listed have been found to be laced with heavy metals such as aluminum, mercury, ammonia, formaldehyde, Glyphosate, green monkey kidneys, human male baby foreskin, and many other well-known Cancer causing agents [27-34]. For this lesson plan, fast foods and poor diet will be addressed. For the other categories mentioned, more lesson plans can be developed to target those specific areas.

\section{The Learning Cycle}

\section{Course Name: Fast Food and Cancer Link}

This is a health and wellness course designed for adolescents in how disease manifests and grows in the body with an unhealthy, toxic, poisonous, Western, fast food diet. This lesson plan can be used to instruct adults of all ages as well. The instructional practices in this lesson plan can benefit the lifespan of any age group. A focus will be placed on why fast foods and common Western diet snacks are far from nutritional, and in fact, quite toxic. This lesson plan can be delivered via: (1) a face-to-face traditional classroom environment, (2) a synchronous online classroom environment, or (3) an asynchronous online classroom environment. As a health and wellness educator, I am always building online health curriculum with asynchronous instructional modules that anyone can access and complete globally and free of charge. Furthermore, I provide tools, resources, real news, real research, and current information to help anyone seeking help with understanding health-related topics, cures, remedies, and naturopathy services.

Unhealthy food choices can be explored via interactive, intuitive, technology-based, asynchronous, differentiated instructional best practices. Furthermore, engagement and motivational techniques are included using interactive, technology and problem-based authentic learning opportunities. The lesson begins with learners viewing the following Voki avatar presentation called Ten horrifying ingredients that prove McDonald's is not fit for consumption http://www.voki.com/presenter/playPresentation.php?i $\mathrm{d}=\mathrm{cef} 37 \mathrm{~d} 99 \mathrm{da6}$ eac37866c2e15c46c39cf

Learners can view the presentation as many times as needed during the group work portion of this lesson on their computer, cell phone, or tablet. In addition, a weblink to the full article online can be provided as well as a transcript (in References section).

\begin{tabular}{|c|c|c|}
\hline \multicolumn{3}{|r|}{ The 7 E's of Learning } \\
\hline E's* & Description** & Activity \\
\hline Engage & $\begin{array}{l}\text { An activity designed to } \\
\text { capture the learner's } \\
\text { attention, help them make } \\
\text { connections and give them a } \\
\text { preview of what they are } \\
\text { going to study. The "Hook" to } \\
\text { raise Essential Questions }\end{array}$ & $\begin{array}{l}\text { Each learner will gather pictures from the Internet of their favorite fast } \\
\text { foods, snacks, and sodas and create an account and a page on } \\
\text { pinterest.com or any other social media site that works in a similar } \\
\text { manner. If this is a lesson plan done in-person, face-to-face, learners can } \\
\text { share their pages with the class and talk about their favorite food choices. } \\
\text { If this is a lesson plan done asynchronously on the Internet, students can } \\
\text { review the pages of other participants posted on the interactive website } \\
\text { where the lesson plan modules are housed. I will show the pages created } \\
\text { by learners on a Smart Board (face-to-face lesson) and I will also upload } \\
\text { the learners' URL links to the website where the asynchronous } \\
\text { curriculum modules are housed. Learners will discuss their food choices } \\
\text { or reflect on the food choices of others if they take the course } \\
\text { asynchronously online. }\end{array}$ \\
\hline \multirow[b]{2}{*}{ Elicit } & \multirow[b]{2}{*}{$\begin{array}{l}\text { An activity designed to } \\
\text { determine learners' prior } \\
\text { knowledge of the topic. Find } \\
\text { out what students know and } \\
\text { reveal Misconceptions }\end{array}$} & Graphic Organizer \#1: Key Topic (see Appendix A) \\
\hline & & $\begin{array}{l}\text { Learners will fill-out the "Main Idea" bubbles in the graphic organizer } \\
\text { with the list of ingredients they learned about in the Voki avatar } \\
\text { Presentation called Ten horrifying ingredients that prove McDonald's is } \\
\text { not fit for consumption. Then, learners will do an Internet search in } \\
\text { groups (selected by the instructor) to identify properties and }\end{array}$ \\
\hline
\end{tabular}




\section{Journal of Natural \& Ayurvedic Medicine}

\begin{tabular}{|c|c|c|}
\hline & & $\begin{array}{l}\text { characteristics of each ingredient they listed. They will list those details } \\
\text { in the sections under each "Main Idea" category. If this lesson is done } \\
\text { online and independently, learners can fill-out the graphic organizer } \\
\text { independently. Learners will add their findings in the "So What? (What's } \\
\text { important to understand about this?) section of the graphic organizer. }\end{array}$ \\
\hline Explore & $\begin{array}{l}\text { An activity designed to place } \\
\text { learners at the center of the } \\
\text { action and calling on them to } \\
\text { seek information or collect } \\
\text { data on the topic. First Hand } \\
\text { experience to build concept. }\end{array}$ & $\begin{array}{l}\text { In their assigned groups or independently depending on how the lesson } \\
\text { is delivered, learners will choose one ingredient they listed in the Graphic } \\
\text { Organizer \#1: Key Topic and do further in-depth research on the Internet } \\
\text { on that ingredient and how it damages the human body. Learners will } \\
\text { create a presentation using the Graphic Organizer \#2: Circles (see } \\
\text { Appendix B). Learners should be as comprehensive as possible and a } \\
\text { deeper Internet research should be done at this point to identify the } \\
\text { harmful affects of their chosen ingredient on the body. The instructor } \\
\text { should make sure each group chooses a different ingredient so that } \\
\text { duplication does not occur and the class as a whole group will benefit } \\
\text { from a multitude of information shared with the whole class later. } \\
\text { Learners are required to add URL links and research sites where they } \\
\text { found helpful information so that others can find those sources as well. } \\
\text { Instructor can advise learners on where to find accurate information } \\
\text { during their search and instructor can provide links embedded in the } \\
\text { online curriculum. }\end{array}$ \\
\hline \multirow{8}{*}{ Explain } & \multirow{8}{*}{$\begin{array}{l}\text { A two-part stage, the first for } \\
\text { learners and the second for } \\
\text { the facilitator. (1) An activity } \\
\text { designed for learners to } \\
\text { report what they learned in } \\
\text { the Explore stage. (2) Create } \\
\text { new vocabulary and a way to } \\
\text { present it; write questions to } \\
\text { assess learners' } \\
\text { understanding of the } \\
\text { concepts. Teacher input, } \\
\text { formalize, concept and } \\
\text { practice. }\end{array}$} & $\begin{array}{l}\text { (1) Learners will create a Prezi, Power Point, Animoto, Youtube, } \\
\text { PowToons, Voki (or other) presentation (in groups or independently) } \\
\text { using pictures and research they compiled and present it to the class. } \\
\text { They can add voice-over to the presentation or they can verbally present } \\
\text { in a face-to-face manner. Examples listed in Appendix D. }\end{array}$ \\
\hline & & $\begin{array}{l}\text { (2) Learners will take } 3 \text { pre-assessments online ( } 5 \text { questions each). The } \\
\text { pre-assessments will not show learners the answers until after they have } \\
\text { taken the same post-assessments in the Evaluate section so they can view } \\
\text { their pre- and post- scores as well as the correct answers. }\end{array}$ \\
\hline & & Curing \& Preventing Cancer The Candida Fungus Lesson \#1 of 3 \\
\hline & & https://www.surveymonkey.com/r/LKSKYJN \\
\hline & & Curing \& Preventing Cancer Backing Soda Protocol Lesson \#2 of 3 \\
\hline & & https://www.surveymonkey.com/r/LK892SM \\
\hline & & Curing \& Preventing Cancer Hydrogen Peroxide Protocol Lesson \#3 of 3 \\
\hline & & https://www.surveymonkey.com/r/VCNVXT2 \\
\hline $\begin{array}{l}\text { Elaborate } \\
\text { or expand }\end{array}$ & $\begin{array}{l}\text { An activity designed in a way } \\
\text { to provide new information } \\
\text { adding to the study, and } \\
\text { identify a problem or issue } \\
\text { for learners to solve or } \\
\text { discuss by applying what they } \\
\text { learned. Deepen } \\
\text { understanding-Apply to } \\
\text { similar contexts. }\end{array}$ & $\begin{array}{c}\text { Learners will choose a partner to research } 2 \text { or } 3 \text { sources listed in the } \\
\text { Appendix C Handout (more or all if they choose). Learners will fill-out } \\
\text { another Graphic Organizer \#1: Key Topic (Appendix A) with the new } \\
\text { information they have learned. }\end{array}$ \\
\hline Extend & $\begin{array}{l}\text { A strategy to help learners } \\
\text { connect the newly acquired } \\
\text { knowledge and skills to new } \\
\text { situations related to the topic. } \\
\text { Apply to unfamiliar different } \\
\text { contexts. }\end{array}$ & $\begin{array}{l}\text { As an extension to the last section, learners will continue their research } \\
\text { using the resources in the handout and investigate the connections } \\
\text { between poor diet and Cancer (Candida), Diabetes, Celiac's, Lupus, } \\
\text { Alzheimer's, Parkinson's, and other health challenges common in } \\
\text { Western nations. Learners will present and share with the class (in a } \\
\text { verbal, whole-class round-table) the information they learned and } \\
\text { provide examples from the resources they engaged with. }\end{array}$ \\
\hline Evaluate & $\begin{array}{l}\text { An activity for learners to } \\
\text { self-assess what they have }\end{array}$ & $\begin{array}{l}\text { (1) Learners will re-take the } 3 \text { pre-assessments online ( } 5 \text { questions each). } \\
\text { This will show them their own improved knowledge from the post- }\end{array}$ \\
\hline
\end{tabular}




\section{Journal of Natural \& Ayurvedic Medicine}

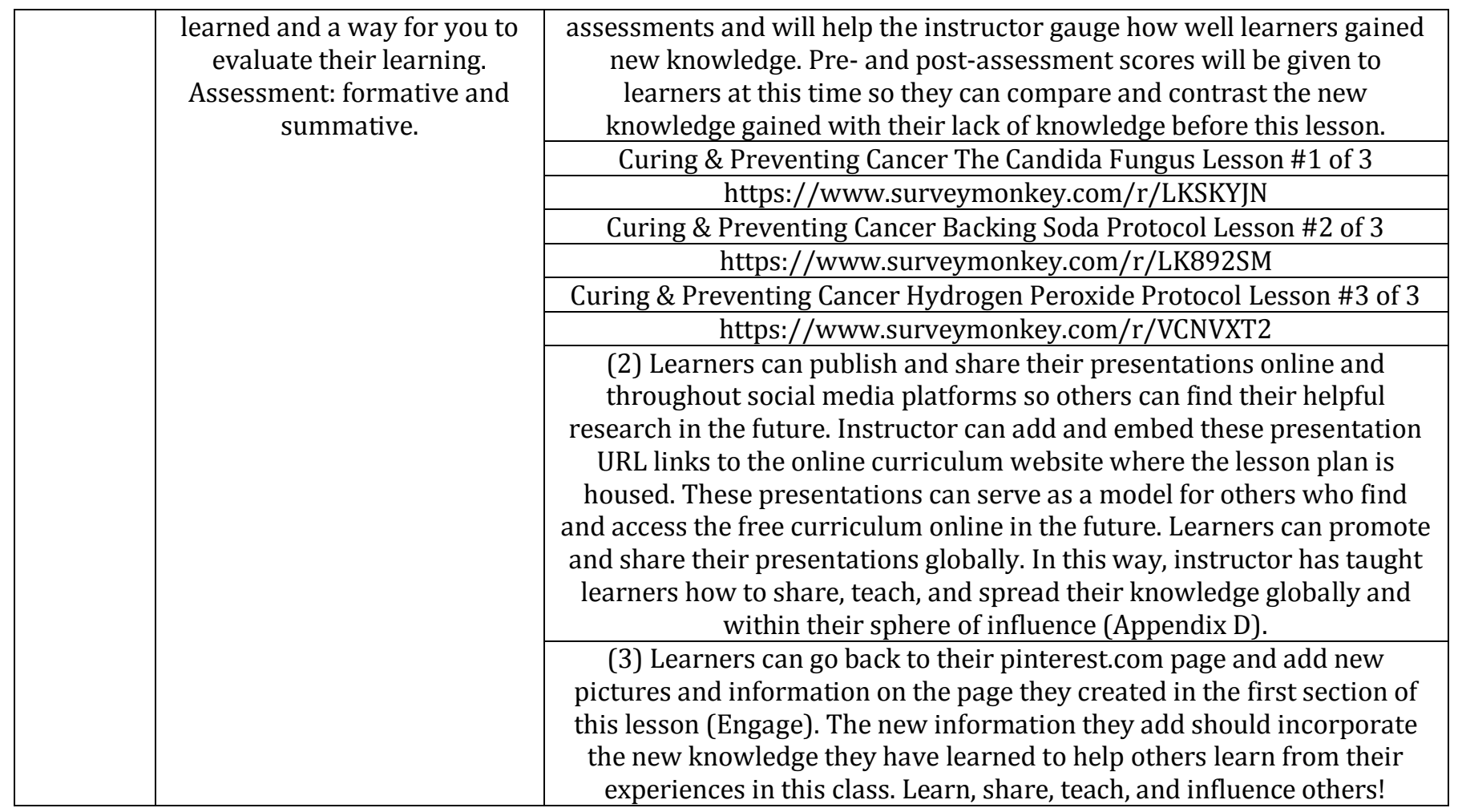

Table 9: The 7 E's of Learning Lesson Plan: Fast Food and Cancer Link.

This lesson plan created for adolescents is an aid to help educators and learners understand the real facts, the real science, and the real news behind the fast food industry in Western nations. Most health education lesson plans concentrate on helping people identify foods that are healthier to eat and exercise plans. Most health lesson plans do not focus on the dangerous, toxic, and even poisonous ingredients found in popular fast food chain restaurants [24]. This lesson plan is created to fill that gap and help individuals understand what is really in the fast foods they are consuming too often. In addition, this lesson plan provides many resources to help learners understand and research the many toxic ingredients that can be found in most fast foods, pre-made, pre-packaged, grocery store foods, snacks, and sodas and how to protect themselves and their families [25].

\section{Conclusion}

In closing, this healthcare educational program seeks to instruct parents and families about the choices they have in seeking out and providing naturopathy healthcare to their family and children. The program uses a Social Cognitive Theory Mapping template which maps out the overall objectives and goals of the program. In addition, the PRECEDE-PROCEED Implementation Model explains how the program will be most effective when mapped out by the expected end results anticipated by the program's goals. Information technology will be used when interpreting educational interventions from theory into practice by mapping out the PRECEDE/PROCEED model to analyze expected outcomes of the program with quantitative and qualitative measures [13]. Finally, a fully developed lesson plan for adolescents and adults has been included to help raise awareness of toxic food, poor health, and disease challenges caused by a Western diet [35-37].

\section{References}

1. Sell K, Amella E, Mueller M, Andrews J, Wachs J (2016) Use of Social Cognitive Theory to assess salient clinical research in chronic disease selfmanagement for older adults: An integrative review. Open Journal of Nursing 6(3): 213-228.

2. Portugal LM (2017) Educating type 2 diabetes adults about naturopathy, alternative medicine benefits. Diabetes Management 7(3).

3. Thalacker KM (2011) Hypertension and the Hmong community: using the health belief model for health promotion. Sage Journals: Health Promot Pract 12(4): 538-43. 


\section{Journal of Natural \& Ayurvedic Medicine}

4. Portugal LM (2017) How to use theory in health education to change lives: Interventions \& strategies. Phoenix, Arizona: Publisher Author.

5. Smith (2015) Healthy living - Health belief models.

6. Baranowski T, Perry CL, Parcel GS (2002) How individuals, environments, and health behavior interact. In: Glanz $\mathrm{K}$, Rimer BK, Lewis FM (Eds.), Health behavior and health education: Theory, research, and practice $3^{\text {rd }}($ Edn), CA: Jossey-Bass San Francisco, pp: 165-184.

7. Davy B, Potter K, Parker DP, Harden S, Hill J, et al. (2013) Feasibility, effectiveness, and perceptions of an Internet-and incentive-based behavioral weight loss intervention for overweight and obese college freshmen: A mixed methods approach. Open Journal of Preventive Medicine 3: 429-440.

8. Dixon FA, Yssel N, McConnell JM, Hardin T (2014) Differentiated instruction, professional development, and teacher efficacy. Journal for the Education of the Gifted 37(2): 111-127.

9. Subban P (2006) Differentiated instruction: A research basis. International Education Journal 7(7): 935-947.

10. Tomlinson CA (2017) How to differentiate instruction in academically diverse classrooms. $3^{\text {rd }}$ (Edn.), VA: ASCD, Alexandria.

11. Sharma M, Branscum P, Atri A (2014) Introduction to community and public health. San Francisco, CA: Jossey-Bass.

12. Viswanath K, Rimer BK, Glanz K (2015) Health behavior: Theory, research, and practice. San Francisco, CA: Jossey-Bass.

13. Weir C, McLeskey N, Brunker C, Brooks D, Supiano MA (2011) The role of information technology in translating educational interventions into practice: An analysis using the PRECEDE/PROCEED model. J Am Med Inform Assoc 18(6): 827-834.

14. Frye AW, Hemmer PA (2012) Program evaluation models and related theories: AMEE Guide No. 67. Med Teach 34(5): e288-e299.

15. Mistry KB, Minkovitz CS, Riley AW, Johnson SB, Grason HA, et al. (2012) A new framework for childhood health promotion: The role of policies and programs in building capacity and foundations of early childhood health. Am J Public Health 102(9): 1688-1696.

16. Whitney W, Dutcher GA, Keselman A (2013) Evaluation of health information outreach: Theory, practice, and future direction. J Med Libr Assoc 101(2): 138-146.

17. Gutierrez Kapheim M, Ramsay J, Schwindt, T, Hunt B, Margellos-Anast H (2015) Utilizing the community health worker model to communicate strategies for asthma self-management and self-advocacy among public housing residents. Journal of Communication in Healthcare 8(2): 95-105.

18. Hagan $T$, Rosenzweig $M$, Zorn $K$, van Londen $G$, Donovan H (2017) Perspectives on self-advocacy: Comparing perceived uses, benefits, and drawbacks among survivors and providers. Oncol Nurs Forum 44(1): 52-59.

19. Kamimura A, Nourian MM, Jess A, Chernenko A, Assasnik N, et al. (2016) Perceived benefits and barriers and self-efficacy affecting the attendance of health education programs among uninsured primary care patients. Eval Program Plan 59: 55-61.

20. Stage CV, Roseno A, Hodges CD, Hovland J, Diaz S, et al. (2016) Implementation of a food-based science curriculum improves fourth-grade educators' selfefficacy for teaching nutrition. Am J Health Educ 47(3): 155-162.

21. Dean E, Greig A, Murphy S, Roots R, Nembhard N, et al. (2016) Raising the priority of lifestyle-related noncommunicable diseases in physical therapy curricula. Phys Ther 96(7): 940-980.

22. Field TA, Beeson ET, Jones LK (2016) Neuroscienceinformed cognitive-behavior therapy in clinical practice: A preliminary study. Journal of Mental Health Counseling, 38(2): 139-154.

23. Giordano G (2009) Solving education's problems effectively: A guide to using the case method. Lanham, MD: R \& L Education.

24. Goodrich A (2017) Ten horrifying ingredients that prove McDonald's is not fit for consumption. Natural News: The World's Top News Source on Natural Health.

25. Krüger $M$, Schledorn $P$, Schrödl W, Hoppe HW, Lutz W, et al, (2014) Detection of Glyphosate residues in animals and humans. J Environ Anal Toxicol 4(2): 210. 


\section{Journal of Natural \& Ayurvedic Medicine}

26. Seneff S, Morley W, Hadden MJ, Michener MC (2016) Does Glyphosate acting as a glycine analogue contributes to ALS? J Bioinfo Proteomics Rev 2(3): 121.

27. Adams M (2016) Glyphosate weed killer unleashes grotesque chemical deformations in farm animals two-headed calves, pigs born with no skin, twisted life forms seem spawned from Hell. The Health Ranger, Natural News.

28. Mercola JM (2013a) Monsanto's Roundup herbicide may be most important factor in development of Autism and other chronic disease.

29. Mercola JM (2013b) Roundup and Glyphosate toxicity have been grossly underestimated.

30. Mercola JM (2012) First-ever lifetime feeding study finds genetically engineered corn causes massive tumors, organ damage, and early death.

31. Samsel A, Seneff S (2017) Glyphosate pathways to modern diseases VI: Prions, amyloidoses and autoimmune neurological diseases. Journal of Biological Physics and Chemistry 17: 8-32.

32. Shah K, Nathanson N (1976) Human exposure to SV40: Review and comment. Am J Epidemiol 103(1): 1-12.

33. Ursino A, Vactruth (2017) Baby foreskin is being used to make vaccines. Health Impact News.

34. Watson T (2017) Fact check: Yes, the CDC and FDA both confirm African Green Monkey kidney cells are put in vaccines used across the US. News Target.

35. Bandura A (2004) Health promotion by social cognitive means. Health Education \& Behavior 31(2): 143-164.

36. Tchouaket E, Broussell A (2013) Using the results of economic evaluations of public health interventions: Challenges and proposals. Journal of Program Evaluation 28(1): 43-66.

37. Isabelle Z (2017) Fake food: GMO crops have been a massive failure on every level. 